\title{
The decline of the chough
}

\section{from Peter D. Moore}

THE results of a new survey ${ }^{1}$ documenting the decline of one of western Europe's cliff birds, the chough (Pyrrhocorax pyrrhocorax), provides a particularly clear example of just how complex and unpredictable are the consequences of changes in land use. The decline of the chough has most probably resulted from a reduction in grazing pressure - including changes from sheep to cattle grazing - on maritime grasslands which have allowed the growth of taller and denser swards of grass.

The survey ${ }^{1}$, by Bullock, Drewett and Mickleburgh, shows that the present chough population (about 900 breeding pairs plus about 800 non-breeding birds in the British Isles) is similar to that recorded in the last survey in 1963, but that the geographical range of the species has greatly contracted since the early nineteenth century. Then it bred in the Channel Islands, along the south coast of Britain from Kent to Cornwall and along most of our rocky western coasts. Now it is limited to west Wales, the Isle of Man, Jura, Islay and Colonsay in Scotland, although it is still widespread in western and southern Ireland.

Conservationists will be relieved to know that the decline of the chough has halted, but the causes of the decline must be understood if the bird's future is to be secured. Human persecution has probably played a part in the decline, but other corvids have been subjected to even greater pressures without succumbing in this way. Habitat disturbance is not likely to have been a serious factor, since these birds are not of a nervous disposition and their nest sites on cliffs are usually inaccessible. Climte may be a factor which confines the chough to maritime areas in northern Europe; it is not so confined in southern Europe and in Asia. Bullock and colleagues show that the highest adult mortality is in February, when frost may limit the availability of the soil invertebrates upon which it largely feeds. Where it occurs inland in Asia, such as in the high plateau of northern Iran, it spends its winter mainly in areas where frost is not too severe, and often in the vicinity of villages.

But it is the feeding studies of Bullock and his colleagues which seem to hold the key to the chough's decline. The chough's preferred feeding habitat is short maritimecliff grassland, followed by short turf on dunes, then by rough (unimproved) grassland. Arable, bog, heathland and improved grassland are neglected by coastal choughs. The preference for short grass can be explained by two factors: the greater ease with which approaching predators can be seen ${ }^{2}$ and its suitability for the chough's feeding habits. Arable and bog habitats either do not contain the right kind of food, or the chough finds it hard to obtain because it has a long bill and feeds by probing relatively deeply into the soil. Preferred food items are tipulid larvae, ants, coleopteran larvae and spiders, suggesting that it is feeding technique rather than the simple availability of food that is important.

Improvement of grassland by fertilization produces a taller sward of higher productivity but lower species density ${ }^{3}$ and will have an adverse effect on the chough population. Sheep-grazed grassland will be preferable to that grazed by cattle, as sheep provide a closer-cropped turf. Just how directly sheep and chough densities are related can be seen on a small island, the Calf of Man. When farming was stopped the chough breeding population fell by 60 per cent over the next ten years. Only when sheep were reintroduced did the chough population gradually return to its former level.

Peter D. Moore is Senior Lecturer in the Department of Plant Sciences, King's College, 68 Half Moon Lane, London SE24 $9 J \mathrm{JF}$.

1. Bullock, I.D., Drewett, D.R. \& Mickleburgh, S.P. Br. Birds 76, 377 (1983).

2. Brough, T. \& Bridgman, C.J. J. appl. Ecol. 17, 243 (1980).

3. Grime, J.P. Plant Strategies and Vegetation Processes (Willey, Chichester, 1979).

\section{Palaeontology}

\section{Archaeopteryx - no new finds after all}

\section{from Michael Howgate}

THE rumours of a new find of the earliest known fossil bird, Archaeopteryx, reported in News $^{l}$ last year, have proved to be unfounded. When, at last, the two new specimens were examined by German palaeontologists, one was found to be the remains of a pterosaur (a not unforgiveable misidentification since the first Archaeopteryx ever discovered was referred to a new species of Pterodactylus in 1855 and the mistake was not recognized until $\left.1970^{2}\right)$; the other, however, somewhat more strangely, turned out to be a fish. So the plethora of current theories ${ }^{3}$ will have to be debated over the bones of the five known skeletons.

The four day symposium devoted entirely to Archaeopteryx being organised by the Jura museum in Eichstatt (in September of next year) seems an appropriate venue for a thorough reexamination of this important fossil. Unfortunately, while the symposium is already oversubscribed with protagonists of the various theories, the subject of their deliberations, the actual specimens, will be in short supply.

Only the Eichstatt specimen, which is a resident feature of the Jura museum, is certain to be present. Of the other specimens, the Munich feather imprint and the very incomplete Tyler museum specimen will possibly be in attendance. The Maxberg (also known as Solenhofen and sometimes Erlangen) specimen was scheduled to attend but the owner, a local private collector, has since changed his mind - negotiations are continuing however.

The key Berlin specimen has been requested and the application has gone to a

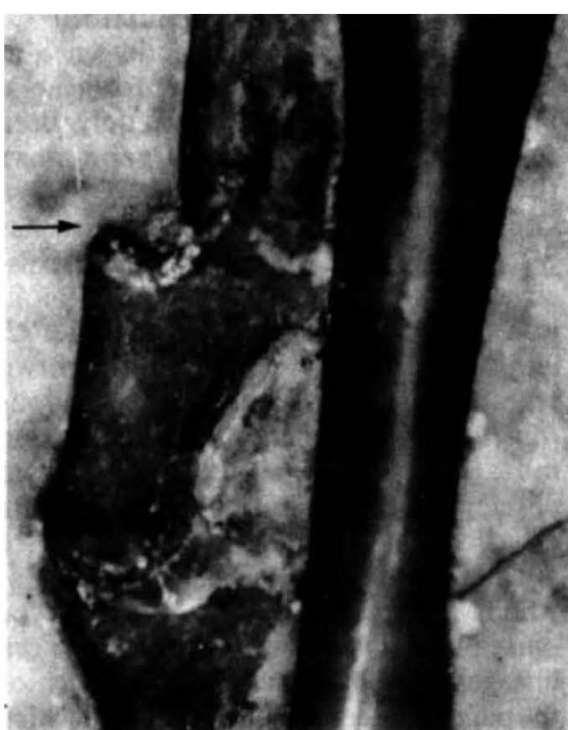

The supposed break (arrowed) in the third topographic digit of the right manus of the Berlin specimen.

higher authority than the Humbolt University Museum for consideration, but the outlook is not very hopeful. As far as the London specimen is concerned, a decision has already been made at the British Museum (Natural History): their specimen will be staying at home. However a detailed video film may be made of the specimen to be shown at the symposium.

It seems a great pity that, with all the expense involved and the time of so many scientists, it is impossible to have all the specimens on hand to adjudicate, on the spot, between the theories. The symposium would provide an ideal opportunity to iron out, at the very least, some of the contradictory interpretations of the osteology on 